\title{
POTENSI WAKAF UNTUK PERUMAHAN DAN PERMUKIMAN RAKYAT
}

\author{
Siswahyudianto \\ siswahyudianto25@gmail.com \\ IAIN Tulung Agung, Jawa Timur
}

\begin{abstract}
ABSTRAK
Wakaf merupakan ibadah yang diutamakan dalam Islam, disamping taqorrub (pendekatan) diri kepada Allah swt, juga sebagai salah satu sarana mewujudkan kesejahteraan sosial dan sekaligus modal dalam perkembangan dan kemajuan agama Islam. Tanah wakaf luasnya mencapai 2.686.536.565,68 $M^{2}$ (2,7 milyar $\left.M^{2}\right)$ tersebar di 466.595 lokasi. Potensi tersebut masih perlu dipetakan dan diinventarisir. Dalam penelitian digunakan metode penelitian eksploratif dan penelitian deskriptif, penelitian kepustakan, penelitian analisis isi, sedangkan data dan sumber data berupa data teoretis yang berupa data primer dan sekunder, dan bersumber dari berbagai kajian ilmiah (buku, jurnal, tesis, skripsi). Metode pengumpulan datanya adalah metode dokumentasi. Hasil Penelitian; Pertama, pemetaan, inventarisasi dan pengembangan potensi harta benda wakaf untuk kepentingan ibadah dan kesejahteraan umum/ masyarakat khususnya pengembangan perumahan dan pemukiman. Instrumen keuangan syariah yang sudah dan sedang dikembangkan dalam skema pembiayaan perumahan dan permukiman antara lain: pembiayaan murabahah, pembiayaan mudharabah, pembiayaan istisna', pembiayaan musyarakah, Pembiayaan Musyarakah Mutanaqishah, Hawalah, Sukuk (SBSN), Wakaf (wakaf tanah dan bangunan, serta wakaf tunai).
\end{abstract}

Kata Kunci: Wakaf, Perumahan atau Pemukiman

\section{Latar Belakang Masalah}

Dalam hadist Rasulullah SAW bersabda bahwa "ketika seorang anak Adam mati maka terputuslah semua hal kecuali 3 yaitu; 1) Ilmu yang bermanfaat, 2) Amal Jariyah, 3) Anak sholeh yang mendoakan orang tuanya. Dan salah satu bentuk amal jariyah adalah wakaf. Wakaf dapat berupa uang atau barang. Di Indonesia yang mayoritas penduduk beragama Islam dianggap sangat perlu untuk mengetahui segala yang terkait wakaf .

Menurut bahasa kata wakaf berasal dari bahasa Arab "waqafa" yang artinya menahan, berhenti, atau diam ditempat.(Aziz, 2010: 397) Sedangkan menurut istilah syara' adalah menahan harta yang bisa dimanfaatkan dalam keadaan barangnya masih tetap (As'ad, 2010: 253). Dalam pasal 5 UU nomor 41/2004 dijelaskan "Wakaf berfungsi mewujudkan potensi dan manfaat ekonomis harta benda wakaf untuk kepentingan ibadah dan kesejahteraan umum. (Aziz, 2010:253)

Wakaf diartikan sebagai "sesuatu yang substansi (wujud aktivanya) dipertahankan, sementara hasil/manfaatnya digunakan sesuai dengan keinginan dari orang yang menyerahkan (waqif)". Wakaf merupakan ibadah yang diutamakan dalam Islam, disamping taqorrub (pendekatan) diri kepada Allah swt, juga sebagai salah satu sarana mewujudkan kesejahteraan sosial dan sekaligus modal dalam perkembangan dan kemajuan agama Islam. Mewakafkan harta yang dimiliki, maka memberikan manfaat yang lebih dari bersedekah, berderma biasa, sebab wakaf itu abadi, tidak boleh dijual, dihibah, atau diwariskan, sehingga hasilnya dapat terus menerus dipergunakan untuk kepentingan masyarakat seperti membangun sekolah, rumah sakit, 
panti asuhan atau jompo, pemakaman dan atau perumahan untuk rakyat kurang mampu serta amal akhirat lain.

\section{Kajian Teori}

Pada dasarnya instrumen wakaf tak kalah strategis untuk peberdayaan masyarakat, pembangunan ekonomi bangsa, dan kesejahteraan sosial. Letak strategis itu terlihat misalnya jika dibanding zakat, salah satu ciri pembeda adalah tugas pengelola. Amil zakat berkewajiban mendistribusikan seluruh harta zakat yang terkumpul kepada delapan golongan (mustahiq). Sedang pengelola wakaf (nazhir) harus menjaga harta wakaf agar tetap utuh dan mengelolanya, yang dapat didistribusikan kepada masyarakat adalah manfaat atau hasil pengelolaan dari harta yang diwakafkan (mauquf). Hasil pengelolaan wakaf bisa dimanfaatkan dari berbagai lapisan masyarakat, tanpa batasan golongan, untuk kesejahteraan sosial, pemberdayaan, dan membangun peradaban umat. Karena itu, keutamaan wakaf terletak pada hartanya yang utuh dan kekal, dan manfaatnya yang terus berlipat dan mengalir abadi. Karena itu, pahala wakaf tidak akan terputus meski wakif (orang yang berwakaf) telah tutup usia.

Wakaf punya dimensi manfaat yang tidak dapat terpisahkan, yaitu meningkatkan kualitas kehidupan masyarakat dengan pendistribusian hasil pengelolaanya dan mengunduh hasil investasi pahala yang ditanam didunia untuk dipetik diakhirat kelak. Berwakaf bagi orang muslim merupakan realisasi ibadah kepada Allah melalui harta benda yang dimilikinya, yaitu dengan melepas benda yang dimilikinya (private benefit) untuk kepentingan umum (social benefit). (Aziz, 2010:254) Pada titik inilah menjadikan pahala wakaf terus mengalir. Pengelolaan dana wakaf sebagai instrument investsi bisa menjadi alternatif kebuntuan pengelolaan harta wakaf. Artinya pemanfaatan yang selama ini terkesan jalan di tempat bisa diterobos. Pengelolaan model ini cukup menarik karena benefit atas investasi tersebut akan dapat dinikmati oleh masyarakat di mana saja. Hal ini dimingkinkan karena benefit atas investasi tersebut berupa cash yang dapat ditransfer ke beneficiary manapun di seluruh dunia. Sementara investasi atas dana wakaf tersebut dapat dilakukan di mana pun tanpa batas negara, mengingat sifat wakaf tunai yang dapat diinvestasikan di negara manapun.

Hal ini diharapkan mampu menjembatani kesenjangan antara si kaya dan si miskin, karena diharapkan terjadi transfer kekayaan (dalam bentuk keuntungan investasi) dari masyarakat kaya kepada masyarakat miskin. Sehingga pada babak berikutnya dapat mewujudkan kesejahteraan masyarakat banyak.

\section{Metode Kajian}

\section{Jenis Penelitian}

Ditinjau dari sudut tempat aktivitas penyelidikan, penelitian ini dapat dimasukkan dalam pola penelitian kepustakan. Penelitian kepustakaan adalah "telaah yang dilaksanakan untuk memecahkan suatu masalah yang pada dasarnya bertumpu pada penelahan kritis dan mendalam terhadap bahan-bahan pustaka yang relevan. Telaah pustaka semacam ini biasanya dilakukan dengan cara mengumpulkan data atau informasi dari berbagai sumber pustaka yang kemudian disajikan dengan cara baru dan atau untuk keperluan baru. Dalam hal ini bahanbahan pustaka itu diperlakukan sebagai sumber ide untuk menggali pemikiran atau gagasan baru, sebagai bahan dasar untuk melakukan reduksi dari pengetahuan yang telah ada, sehingga kerangka teori baru dapat dikembangkan 
atau sebagai dasar pemecahan masalah." (Pedoman Penulisan Karya Ilmiah, 2000: 2)

Penelitian ini dilakukan dengan mengumpulkan data dan informasi yang terkait dengan masalah yang dikaji dengan berbagai macam literatur di perpustakaan seperti buku ilmiah, juga literatur yang diakses melalui internet.

2. Data dan Sumber data

Data menurut Suharsimi Arikunto, adalah "hasil pencatatan peneliti, baik yang berupa fakta atau angka". (Arikunto, 1999: 102). Data yang harus dicari oleh penulis yang berkaitan dengan rumusan masalah. Apabila diperhatikan dari segi tempat asalnya, maka data yang harus dikumpulkan oleh peneliti adalah berupa data teoretis.

Sumber data menurut Suharsimi Arikunto, adalah "subyek dari mana data diperoleh". Apabila dilihat darimana data diperoleh sumber data dapat dibagi menjadi dua yaitu:

a. Sumber Data Primer

Sumber data primer adalah bahan pustaka yang berisikan pengetahuan ilmiah yang baru atau mutakhir, ataupun pengertian baru tentang fakta yang diketahui maupun mengenai gagasan (ide). Adapun sumber primer yang digunakan dalam penelitian ini adalah buku-buku yang berkaiatan langsung dengan permasalahan yang menjadi fokus kajian dalam penelitian ini. (Waloyo, 1996: 51)

b. Sumber Data Sekunder

Yaitu bahan pustaka/ sumber data sebagai penunjang dalam skripsi ini, seperti semua buku yang ada hubungannya dengan judul skripsi ini secara tidak langsung dan majalah, akses internet, jurnal bulletin dokumentasi dan lain-lain.

\section{Pendekatan Kajian}

Pendekatan kajian yang penulis gunakan dalam skripsi ini adalah deskriptif analisis yaitu mendiskripsikan jawaban yang tercantum dalam rumusan masalah guna dianalisis sesuai dengan data-data yang diperoleh.

4. Metode dan Instrumen Pengumpulan Data

Metode dan instrument pengumpulan data yang digunakan dalam kajian ini adalah metode dokumentasi yaitu cara pencarian data yang akan dibahas ataupun teori-teori yang akan digunakan dalam rumusan data yang kemudian disimpulkan. Data ini dapat berupa transkip, catatan, majalah, prasasti dan sebagainya.

\section{Hasil Kajian}

Amanat Undang-Undang Dasar 1945 Amandemen II pasal 28 H, UU No. 4 Tahun1992 Tentang Perkim, dan UU No. 39 Tahun 1999 Tentang HAM disebutkan bahwa hunian yang layak merupakan hak dasar Warga Negara Indonesia. Visi pembangunan nasional tahun 2005-2025 adalah Indonesia Yang Mandiri, Maju, Adil Dan Makmur yang akan diwujudkan melalui salah satu misinya yaitu mewujudkan pemerataan pembangunan dan berkeadilan dengan meningkatkan pembangunan daerah; mengurangi kesenjangan social secara menyeluruh, keberpihakan kepada masyarakat, kelompok dan wilayah/daerah yang masih lemah, menanggulangi kemiskinan dan pengangguran secara drastis, menyediakan akses yang sama bagi 
masyarakat terhadap berbagai pelayanan social serta sarana dan prasarana ekonomi, serta menghilangkan diskriminasi dalam berbagai aspek termasuk gender.

Undang-Undang Nomor 1 Tahun 2011 tentang Perumahan dan Kawasan Permukiman mengamanatkan, setiap orang berhak hidup sejahtera lahir dan batin, bertempat tinggal, dan mendapatkan lingkungan hidup yang baik dan sehat. Itu semua merupakan kebutuhan dasar manusia, dan mempunyai peran strategis dalam pembentukan watak serta kepribadian bangsa sebagai salah satu upaya membangun manusia Indonesia seutuhnya, berjati diri, mandiri, dan produktif. Berdasarkan amanat tersebut, setiap warga negara mempunyai hak untuk menempati, menikmati, atau memiliki rumah yang layak dalam lingkungan yang sehat, aman, serasi, dan teratur.

Menurut Undang-Undang Nomor 41 Tahun 2004 Tentang Wakaf, bahwa wakaf dikelompokkan menjadi: (1) wakaf benda tidak bergerak seperti tanah dan atau bangunan; dan(2) wakaf benda bergerak seperti uang (cash waqf).

Wakaf tunai dapat dipergunakan untuk memproduktifkan asset-asset wakaf yang sekarang tersebar di banyak negeri kaum muslimin. Dengan demikian, wakaf tunai dapat digunakan sebagai sarana untuk memotivasi dana masyarakat dengan jangkauan lapisan masyarakat yang lebih luas ke dalam bentuk modal investasi produktif, dan dapat dipergunakan untuk memproduktifkan asset wakaf yang sudah ada. Merupakan hal sangat penting untuk memberdayakan wakaf, baik wakaf benda bergerak maupun benda tidak bergerak agar dapat meningkatkan kesejahteraan umat Islam pada khususnya dan masyarakat pada umumnya serta meningkatkan perkembangan Islam di Indonesia. Pengelolaan wakaf benda bergerak dikembangkan melalui lembaga-lembaga perbankan atau badan usaha dalam bentuk investasi yang hasilnya dipergunakan untuk keperluan social, seperti untuk meningkatkan pendidikan Islam, pengembangan rumah sakit Islam, bantuan pemberdayaan ekonomi umat, bantuan penelitian, bantuan pendidikan dan bantuan atau pengembangan sarana dan prasarana ibadah. Sedangkan wakaf benda tidak bergerak yang sudah ada di kalangan masyarakat perlu diamankan, dan dalam hal benda wakaf yang mempunyai nilai produktif perlu didorong untuk dilakukan pengelolaannya yang bersifat produktif. Hal ini tentunya harus didukung dengan sosialisasi yang efektif kepada para nâzir agar dapat mengelola wakaf dengan optimal. Menurut penulis, Wakaf tunai dapat digunakan untuk menghidupkan wakaf-wakaf non tunai (tanah, bangunan) menjadi produktif yang hasilnya dapat digunakan untuk kepentingan ibadah dan kesejahteraan umum/masyarakat termasuk untuk bidang perumahan dan permukiman bagi Masyarakat Berpenghasilan Rendah (MBR).

Kajian Berdasarkan data Departemen Agama dan BWI tahun 2007, tanah wakaf luasnya mencapai $2.686 .536 .565,68 \mathrm{M}^{2}\left(2,7\right.$ milyar $\left.\mathrm{M}^{2}\right)$ tersebar di 466.595 lokasi. Potensi tersebut masih perlu dipetakan dan diinventarisir. Pertama, pemetaan, inventarisasi dan pengembangan potensi harta benda wakaf untuk kepentingan ibadah dan kesejahteraan umum/ masyarakat khususnya pengembangan perumahan dan pemukiman. Kedua, fasilitasi dukungan pembiayaan perumahan dan permukiman melalui instumen keuangan syariah dan wakaf. Ketiga, melakukan kajian skema pembiayaan syariah

untuk

pengembangan perumahan dan permukiman. Dan keempat adalah melakukan kajian pendayagunaan wakaf untuk pengembangan perumahan dan permukiman. Dari keseluruhan tanah wakaf yang ada, penggunaannya didominasi wakaf fisik yang bersifat sosial, diantaranya $68 \%$ digunakan untuk tempat ibadah, $8,51 \%$ untuk pendidikan, 8,40\% untuk kuburan dan 14,60\% untuk lain-lain. Wakaf di Indonesia lebih banyak dikelola oleh perseorangan (66\%), organisasi kemasyarakatan (16\%) dan 
badan hukum (18\%). Harta wakaf juga lebih banyak yang tidak menghasilkan (77\%) dari pada yang menghasilkan atau produktif $(23 \%)$.

Temuan lainnya, benda wakaf lebih banyak berada di wilayah pedesaan (59\%) dari pada perkotaan $(41 \%)$. Mengingat masalah ketersediaan/keterbatasan lahan dan masalah pembiayaan merupakan bagian dari permasalahan yang dihadapi dalam mencapai target pembangunan perumahan dan permukiman, maka pemanfaatan wakaf baik berupa wakaf tanah maupun wakaf tunai untuk membantu pemenuhan rumah layak huni bagi masyarakat, khususnya masyarakat berpenghasilan rendah (MBR), adalah salah satu solusi alternatif dalam mengatasi berbagai permasalahan tersebut (sepanjang diamanatkan oleh Wakif).

Perlu dilakukan pemetaan, inventarisasi dan pengembangan potensi harta benda wakaf untuk kepentingan ibadah dan kesejahteraan umum/masyarakat khususnya untuk pembangunan perumahan dan permukiman. Perlu fasilitasi dan kajian skema pembiayaan syariah dan wakaf untuk pengembangunan perumahan dan permukiman.

Instrumen keuangan syariah yang sudah dan sedang dikembangkan dalam skema pembiayaan perumahan dan permukiman antara lain: pembiayaan murabahah, pembiayaan mudharabah, pembiayaan istisna', pembiayaan musyarakah, Pembiayaan Musyarakah Mutanaqishah, Hawalah, Sukuk (SBSN), Wakaf (wakaf tanah dan bangunan, serta wakaf tunai).

Menurut Karim (2004;88), Murabahah, yang berasal dari Ribhu (keuntungan), adalah transaksi jual beli di mana bank menyebut jumlah keuntungannya. Bank bertindak sebagai penjual, sementa nasabah bertindak sebagai pembeli. Harga jual adalah harga beli bank dari pemasok ditambah keuntungan (Margin).

Menurut Zulkifli (2003;90), Transaksi Murabahah adalah skim dimana bank bertindak selaku penjual disatu sisi, dan disisi lain bertindak selaku pembeli. Kemudian bank akan menjualnya kembali kepada pembeli dengan harga beli ditambah margin (Ribhun) yang disepakati.

Menurut Nazir dan Hassanuddin (2004;403), Ensiklopedi Ekonomi dan Perbankan Syariah. Murabahah adalah akad jual beli antara bank selaku penyedia barang dengan nasabah yang memesan untuk membeli barang. Dari transaksi tersebut bank mendapatkan keuntungan jual beli yang disepakati bersama. Atau Murabahah adalah jasa pembiayaan oleh bank melalui transaksi jual beli dengan nasabah dengan cara cicilan. Dalam hal ini bank membiayai pembelian barang yang dibutuhkan oleh nasabah dengan membeli barang tersebut dari pemasok kemudian menjualnya kepada nasabah dengan menambahkan biaya keuntungan (Cost-Plus Profit) Dan ini dilakukan melalui perundingan terlebih dahulu antara bank dengan nasabah yang bersangkutan.

Mudharabah berasal dari kata dharb, berarti memukul atau berjalan. Pengertian memukul atau berjalan ini lebih tepatnya adalah proses seseorang memukulkan kakinya dalam menjalankan usaha. Dan secara teknis, mudharabah adalah akad kerjasama usaha antara dua pihak dimana pihak pertama (shohibul maal) menyediakan seluruh $(100 \%)$ modal, sedangkan pihak kedua menjadi pengelola. Keuntungan usaha dibagi menurut kesepakatan yang dituangkan dalam kontrak, sedangkan apabila rugi ditanggung oleh pemilik modal selama kerugian itu bukan akibat dari kelalaian si pengelola. Jika kerugian akibat dari kelalaian pengelola, si pengelola harus bertanggung jawab atas kerugian tersebut.(Antonio, 2001: 95)

Mudharabah adalah akad kerjasama usaha antara dua pihak dimana pihak pertama (pemilik dana) menyediakan seluruh dana, sedangkan pihak kedua (pengelola dana) bertindak selaku pengelola, dan keuntungan usaha dibagi di antara mereka sesuai kesepakatan sedangkan kerugian finansial hanya ditanggung oleh pengelola dana.( Penyataan Standar Akuntansi Keuangan No. 105 tentang Mudharabah) 
Mudharabah yaitu akad kerjasama suatu usaha antara dua pihak di mana pihak pertama (malik, shahib al-mal, LKS) menyediakan seluruh modal, sedang pihak kedua ('amil, mudharib, nasabah) bertindak selaku pengelola, dan keuntungan usaha dibagi di antara mereka sesuai kesepakatan yang dituangkan dalam kontrak. (Fatwa Dewan Syariah Nasional No. 7 tentang Mudharabah)

Seiring dengan berkembangnya institusi keuangan Islam di Indonesia, maka suatu aturan hukum turut pula dikembangkan untuk melegalisasi serta melindungi akad-akad yang sesuai Syari'ah Islam diterapkan dalam Sistem Keuangan Islam di Indonesia. Maka dari itu, Dewan Syari'ah Nasional - Majelis Ulama Indonesia telah mengeluarkan fatwa No: 12/DSN-MUI/IV/2000 tentang Hawalah disebutkan bahwa pernyataan ijab dan qabul harus dinyatakan oleh para pihak untuk menunjukkan kehendak mereka dalam mengadakan kontrak (akad).

Dalam perniagaan, terkadang pembayaran atas suatu transaksi tidak dilakukan secara tunai, namun dengan adanya tempo waktu tertentu. Disisi lain pihak yang melakukan penjualan atau pengiriman barang membutuhkan uang tunai dengan segera, guna memutar dan menjalankan perniagaan kembali. Peluang ini dapat dibaca oleh pihak perbankan dengan menwarkan jasa factoring/ anjak piutang, kepada pihak ketiga memindahkan piutang itu kepada bank, pihak bank lalu membayar piutang tersebut, dan selanjutnya bank akan mengalihkan kepada pihak ketiga.

Melihat praktek tersebut, factoring identik dengan konsep hawalah dengan term fiqih. Secara linguistik, hawalah berarti memindahkan, perpindahan. Secara istilah, hawalah adalah pengalihan utang dari orang yang berutang kepada orang lain yang wajib menanggungnya, dalam istilah para ulama, hal ini merupakan pemindahan beban utang dari muhil (orang yang berutang) menjadi tanggungan muhal 'alaih atau orang yang berkewajiban membayar utang.

Dalam operasional bank, hawalah adalah pemindahan utang piutang seorang nasabah (muhil) kepada pihak bank (muhal 'alaih) dari seorang nasabah yang lain (muhal). Hawalah terjadi ketika nasabah pertama (muhil) meminta pihak bank (muhal ilaih) untuk membayarkan terlebih dahulu piutang yang timbul dari jual belinya. Pada saat piutang tersebut jatuh tempo, nasabah yang berutang (muhal) akan membayar utangnya kepada pihak bank, bukan kepada nasabah pertama. Sedangkan, pihak bank (muhal ilaih) akan memproleh imbalan (fee) sebagai jasa pemindahan piutang ini melihat praktek ini, Dewan Syariah Nasional merasa perlu untuk menetapkan Fatwa agar praktek tersebut sesuai dengan ketentuan syariah, dan sekaligus dapat dijadikan pedoman bagi lembaga keuangan syariah dalam menjalankan operasionalnya.

Dalam fatwa nomor 32/DSN-MUI/IX/2002, Dewan Syari'ah Nasional-Majelis Ulama Indonesia mendefinisikan sukuk sebagai surat berharga jangka panjang berdasarkan prinsip syari'ah yang dikeluarkan emiten kepada pemegang obligasi syari'ah yang mewajibkan emiten membayar pendapatan kepada pemegang saat obligasi syari'ah berupa bagi hasil margin atau fee serta membayar kembali dana obligasi saat jatuh tempo. Sukuk dapat pula diartikan dengan efek syari'ah berupa sertifikat atau bukti kepemilikan yang bernilai sama dan mewakili bagian penyertaan yang tidak terpisahkan atau tidak terbagi atas:

1. Kepemilikan asset berwujud tertentu

2. Nilai manfaatn dan jasa atas asset proyek tertentu atatu aktivitas investasi tertentu atau

3. Kepemilikan atas asset proyek tertentu atau aktivitas investasi tertentu.(Muhammad, 2014: 602) 
Pada prinsipnya sukuk mirip seperti obligasi konvensional dengan perbedaan pokok antara lain berupa penggunaan konsep imbalan dan bagi hasil sebagai pengganti bunga, adanya suatu transaksi pendukung (underlying transaction) berupa sejumlah tertentu asset yang menjadi dasar penerbitan sukuk dan adanya akad atau perjanjian antara para pihak yang disusun berdasarkan prinsip-prinsip syariah. Selain itu, sukuk juga harus distruktur secara syariah agara instrument keuangan ini aman dan terbebas dari riba, gharar dan maysir.

Sukuk bukan merupakan utang berbunga tetap, tetapi lebih merupakan penyertaan dana (investasi) yang didasarkan pada prinsip bagi hasil jika menggunakan akad mudharabah dan musyarakah. Transaksinya bukan akad hutang piutang melainkan penyertaan.

\section{Kesimpulan}

Wakaf merupakan sesuatu yang substansi (wujud aktivanya) dipertahankan, sementara hasil/manfaatnya digunakan sesuai dengan keinginan dari orang yang menyerahkan (waqif). Wakaf merupakan ibadah yang diutamakan dalam Islam, disamping taqorrub (pendekatan) diri kepada Allah swt, juga sebagai salah satu sarana mewujudkan kesejahteraan sosial dan sekaligus modal dalam perkembangan dan kemajuan agama Islam. Mewakafkan harta yang dimiliki, maka memberikan manfaat yang lebih dari bersedekah, berderma biasa, sebab wakaf itu abadi, tidak boleh dijual, dihibah, atau diwariskan, sehingga hasilnya dapat terus menerus dipergunakan untuk kepentingan masyarakat seperti membangun sekolah, rumah sakit, panti asuhan atau jompo, pemakaman dan atau perumahan untuk rakyat kurang mampu serta amal akhirat lain. Hal ini diharapkan mampu menjembatani kesenjangan antara si kaya dan si miskin, karena diharapkan terjadi transfer kekayaan (dalam bentuk keuntungan investasi) dari masyarakat kaya kepada masyarakat miskin. Sehingga pada babak berikutnya dapat mewujudkan kesejahteraan masyarakat banyak.

\section{Saran}

Terobosan baru tanah wakaf sebagai sarana perumahan dan pemukiman bagi masyarakat berpenghasilan rendah (MBR) perlu mendapatkan dukungan secara konstitusional dari pemerintah, sehingga regulasi disertai juklak dan juknis serta program-program harus dimotori oleh pemerintah sendiri, sehingga pemanfaatan tanah wakaf ini tidak menimbulkan kesenjangan sosial

\section{DAFTAR RUJUKAN}

al-Alabiq, Adijani. 1997. Perwakafan Tanah di Indonesia, Jakarta: Raja Grafindo Persada.

Antonio, Muhammad Syafi'i. 2001. Bank Syariah dari Teori ke Praktek. Jakarta: Gema Insani Press.

Arikunto, Suharsimi.1999. Prosedur Penelitian Suatu Pendekatan. Jakarta: Bina Aksara.

Azzam, Abdul Aziz Muhammad. 2010. Fiqih Muamalat, Jakarta: Amzah.

Aziz, Abdul. 2010. Manajemen Investasi Syariah, Bandung: Alfabeta.

Djunaedi, Ahmad dkk., 2003. Fiqh Wakaf, Jakarta: Rineka Cipta.

Fatwa Dewan Syariah Nasional (DSN).

Karim, Adiwarman. 2002. Ekonomi Mikro Islami. Jakarta: The International Institute of Islamic Thought Indonesia.

Mubaintoro, Tirto (Deputi Menpera Bidang Pembiayaan), Potensi Instrumen Pembiayaan 
Syariah dan Wakaf Untuk Pembangunan Perumahan dan Permukiman, (Disampaikan dalam Acara Seminar Sehari potensi Wakaf Untuk Bidang Perumahan Rakyat Kerjasama Kemenpera dan Masyarakat Ekonomi Syariah, Juni 2009.

Muhammad. 2014. Manajemen Keuangan Syariah, Yogyakarta:UPP STIM YKPN.

Pernyataan Standar Akuntansi Keuangan (PSAK).

Tim, Pedoman Penulisan Karya Ilmiah, ed. 4 (Biro Administrasi Akademik Perencanaan dan Sistem Informasi, Universitas Negeri Malang, 2000)

Undang-Undang Nomor 41 Tahun 2004 Tentang Wakaf.

Waloyo, Bambang. 1996. Penelitian Hukum Dalam Praktek Jakarta: Sinar Grafik. 